\title{
Non-genetic factors affecting live weight and daily gain weight in Serrana Transmontano kids
}

\author{
M.R. Jiménez-Badillo ${ }^{\mathrm{a}, \mathrm{b}, \mathrm{c}}$, S. Rodrigues ${ }^{\mathrm{a}}$, C. Sañudo $^{\mathrm{c}}$, A. Teixeira ${ }^{\mathrm{a}, *}$ \\ a Escola Superior Agrária de Bragança, Centro de Investigação de Montanha, Campus de Santa Apolónia, Apdo, 1172, 5300 Bragança, Portugal \\ b Universidad Nacional Autónoma de México, Mexico \\ c Universidad de Zaragoza, Facultad de Veterinaria, Spain
}

\begin{abstract}
A B S T R A C T
The objective of this study was to evaluate the effect of some non-genetic factors on birth weight, weaning weight and daily gain weight in Serrana Transmontano kids. Data from 8930 records were analysed. Results showed that birth weight (BW), adjusted live weight at 30 days of age (W30), adjusted weaning weight at 60 days of age (WW), average daily gain from birth until 30 days of age (ADG30) and average daily gain from birth until 60 days of age (ADG60) were influenced by sex, age of dam and birth season. BW, W30, WW, ADG30 and ADG60 of males were higher than female. The same variables increased with the dam's age. Kids born in autumn were heavier than those born in spring, winter and summer. W30 was lower in kids born in winter. The WW of kids born in spring was higher than of those born in winter, autumn and summer and the ADG30 of kids born in spring and summer were higher than those born in autumn or winter. ADG60 was higher for kids born in spring. Kids born single were heavier at BW, W30 and ADG30 whilst kids born triple were lighter. Males showed the greatest weights and average daily gains, in the offspring of 3-5 years old females, as well as in single born and in those which were born in autumn.
\end{abstract}

\section{Introduction}

About 547,000 goats and 1165 tonnes of goat meat production have been estimated in Portugal (FAO, 2006). In the northeast of Portugal (Trás-os-Montes region) an extensive production system emphasizes the importance of native breeds and their products.

Looking for new sources of farm income and ways to diversify their operations, farmers have adopted the European Union (EU) policy of animal production extensification and to encourage a sustainable development of local breeds. The European system for the protection of food labels is based on three elements: Protected Designation of Origin (PDO), Protected Geographic Indication (PGI) and
Traditional Speciality Guaranteed (TSG). In Portugal there are four PGI, named Cabrito das Terras Altas do Minho, Cabrito de Barroso, Cabrito da Gralheira, Cabrito da Beira, and one PDO, Cabrito Transmontano biotype of the Serrana breed (Teixeira, 2003 and IDRHa, 2005) on which this study was focused.

In Mediterranean Europe, particularly Spain and Portugal, there is an important demand for meat from young goats (milk fed kids), often slaughtered near 60 days of age (Teixeira and Delfa, 1993). In order to increase meat production, efforts should be done to improve the reproductive rate, growth rate and carcass and meat quality. The different growth parameters are therefore potential economic traits to be included in the goat breeding programme in Portugal. Non-genetic factors include animal development conditions, i.e., year, season, age of dam, and aspects inherent to the animal such as sex and type of birth. Several studies reported non-genetic effects on growth of kids in different 
countries and breeds (Amoah et al., 1996; Alexandre et al., 1999; Dhanda et al., 2003; Kadim et al., 2003; Liu et al., 2005). Serrana is the most important goat breed in Portugal, with a population estimated in 241,000 adult animals. A large proportion of goat flocks are kept on transhumance and extensive systems with natural meadows, forest meadows and stubble fields. With a fertility rate between 99 and $95 \%$, a prolificacy around $180 \%$ and the adult weight about $40-50 \mathrm{~kg}$ for males and $25-40 \mathrm{~kg}$ for females, the Serrana goat is generally raised to produce milk for cheese making but also produces a meat PDO (ANCRAS, 2009). However, very little is known about meat production traits. So, the aim of this study was to evaluate the effects of some nongenetic factors on weights at different ages and on average daily gain of Transmontano kids.

\section{Materials and methods}

\subsection{Animal and traits}

Data analysed in this study represent a three years' performance records of the Serrana Goats Breed Association (Associação Nacional de Caprinicultores da Raça Serrana: ANCRAS) and includes 8930 animals recorded. All animal procedures were conducted in compliance with management, housing, and husbandry conditions conformed to EU guidelines. The research project was approved by the Agro program of the INIAP (Instituto Nacional de Investigação Agrária e das Pescas-Agriculture and Fishery National Research Institute) from Portuguese Agricultural Ministry.

The production system is typical of the region and similar management and nutritional practices are followed by all the farmers (Teixeira et al., 1998). Adult goats and offspring were maintained under a grazing feeding system in natural rangelands. Males remained with the flock during the whole year with natural mating. In the present study, the weight of new born kids was taken within $24 \mathrm{~h}$ of birth. Kid's live weight was recorded at a 15 days interval from birth to weaning. Kids were weaned at nearly two months of age.

The traits analysed were birth weight (BW, $n=8930$ ), adjusted live weight at 30 days (W30, $n=6495$ ), adjusted weaning live weight at 60 days (WW, $n=692$ ), average daily gain from birth to 30 days (ADG30, $n=6495$ ) and average daily gain from birth to 60 days (ADG60, $n=692$ ). The number of records is reducing between 30 and 60 days as result of a great market demand for young kids producing light carcasses, mainly in periods as Christmas and Easter.

\subsection{Statistical analysis}

Data were analysed using the Mixed Model procedure of SAS (SAS, 2003). The model included sex of kids (male, female), type of birth (single, twin, triple), birth season (spring, summer, autumn, winter), and age of dam $(1,2,3,4, \geq 5$ year) as fixed effects and birth year (1, 2 and 3 year) as a random effect. Kids born as twin or triple and reared as single were excluded from the database so long as those animals traduce the effect of birth type. In the initial model, all two-way interactions were found nonsignificant and were excluded from the final model. Means were compared using the Bonferroni test.

\section{Results and discussion}

The overall mean birth weight was $2.3 \pm 0.41 \mathrm{~kg}$, W30 was $5.8 \pm 0.02 \mathrm{~kg}$ and weaning weight was $8.2 \pm 0.07 \mathrm{~kg}$ (Table 1). The average BW and WW of kids in this study was within the estimated range $(1.8-3.3 \mathrm{~kg}$ and $6.5-11.6 \mathrm{~kg}$ respectively) as reported in other native goats as Batina (Mahgoub and Lodge, 1996), Dhofari (Mahgoub and Lu, 1998; Kadim et al., 2003), Creole (Alexandre et al., 1999), Emirati (Al-Shorepy et al., 2002), Girgentana (Portolano et al., 2002) and Jabal Akhdar (Kadim et al., 2003).
As it can be seen in Table 1, kids had a faster growth rate from birth to 30 days than from birth to 60 days as a result of the suckling period, showing an excellent milk production potential of the mothers. In fact, Serrana breed is a milk breed producing a cheese with PDO label. Husain et al. (1996) and Dhanda et al. (2003) indicated that the average daily gain in kids decreased with the age increase, from 3 until 12 months of age and between 93 and 254 days of age, respectively. In other breeds, such as Creole (Alexandre et al., 1999), Dhofari, Batina (Kadim et al., 2003), Spanish $\times$ Kiko, Spanish $\times$ Boer (Browning et al., 2004) and Saanen (Ugur et al., 2004) the reported interval of average daily gain from birth to weaning is within $65-140 \mathrm{~g}$, corresponding to $60-90$ days, $74-78$ days, 14 weeks, $45-60$ days weaning age, respectively.

\subsection{Effect of sex}

Table 1 show that male kids were heavier than females. These results agree with other studies by several authors (Amoah et al., 1996; Husain et al., 1996; Mahgoub and Lodge, 1996; Alexandre et al., 1999; Al-Shorepy et al., 2002; Portolano et al., 2002; Browning et al., 2004; Liu et al., 2005).

ADG30 for male kids was higher than females as it can be seen in Table 1. ADG reported by several authors (Mahgoub and Lodge, 1996; Mahgoub and Lu, 1998; Browning et al., 2004; Ugur et al., 2004) indicated sex differences between 30 and $145 \mathrm{~g}$, what is in agreement with our results.

\subsection{Effect of type of birth}

Kids born as singles (Table 1) were heavier than twins and triplets according to the results reported in the literature (Das and Sendalo, 1992; Husain et al., 1996; Mahgoub and Lu, 1998; Mourad and Anous, 1998; Alexandre et al., 1999; Al-Shorepy et al., 2002; Portolano et al., 2002; Browning et al., 2004; Liu et al., 2005). This effect is attributed mainly to the fact that single kids do not have to compete for space or nutrients in their mother's uterus, unlike what happens when two or three kids were developed. Regarding to W30, the differences were of $0.41 \mathrm{~kg}$ between single and twins and $0.60 \mathrm{~kg}$ between single and triplet, whereas between twin and triplet it was of only $0.19 \mathrm{~kg}$. The type of birth did not significantly affect the weaning. The ADG30 in single born kids was $12.2 \mathrm{~g}$ higher than in twin and $16.9 \mathrm{~g}$ than in triplet born kids, whilst no differences were found between twin and triplet kids (Table 1). Despite the presence of numerical differences in the ADG60, they were not statistically significant. The advantage shown by single born kid over the twin and triplet ones in daily weight gain agrees with results found in Black Bengal and Angora kids (Husain et al., 1996; Liu et al., 2005).

\subsection{Effect of age of dam}

Means of dam age effect, shown in Table 1, indicate that does kidding for the first year had lighter kids than those kidding for the 2, 3, 4 and $\geq 5$ year and the same were observed in the W30 and WW. The BW and WW of kids 
Table 1

Least squares mean ( \pm S.E.) for birth weight (BW), adjusted live weight at 30 days of age (W30), average daily gain from birth until 30 days (ADG30), adjusted weaning weight (WW), and average daily gain from birth until 60 days (ADG60) by sex, type of birth, age of dam, and birth season.

\begin{tabular}{|c|c|c|c|c|c|c|c|c|}
\hline Effects & $N$ & BW (kg) & $N$ & W30 (kg) & ADG30 (g) & $N$ & WW (kg) & ADG60 (g) \\
\hline Mean & 8930 & $2.34 \pm 0.01$ & 6495 & $5.82 \pm 0.02$ & $117.49 \pm 0.52$ & 692 & $8.17 \pm 0.07$ & $98.12 \pm 1.20$ \\
\hline Sex & & $* * *$ & & ${ }^{* * *}$ & $* * *$ & & $* * *$ & $* * *$ \\
\hline Male & 4671 & $2.44 \pm 0.06^{\mathrm{a}}$ & 3386 & $5.92 \pm 0.09^{a}$ & $117.92 \pm 4.69^{a}$ & 348 & $8.76 \pm 0.19^{a}$ & $104.79 \pm 2.69^{a}$ \\
\hline Female & 4259 & $2.17 \pm 0.06^{\mathrm{b}}$ & 3109 & $5.50 \pm 0.09^{b}$ & $112.24 \pm 4.69^{b}$ & 344 & $8.16 \pm 0.19^{b}$ & $98.47 \pm 2.69^{b}$ \\
\hline Type of birth & & $* * *$ & & $* * *$ & $* * *$ & & NS & NS \\
\hline Single & 3414 & $2.35 \pm 0.06^{\mathrm{a}}$ & 2522 & $6.04 \pm 0.09^{a}$ & $124.78 \pm 4.64^{\mathrm{a}}$ & 287 & $8.65 \pm 0.15$ & $106.56 \pm 1.97$ \\
\hline Twins & 5115 & $2.30 \pm 0.06^{\mathrm{b}}$ & 3694 & $5.63 \pm 0.09^{b}$ & $112.58 \pm 4.63^{b}$ & 384 & $8.33 \pm 0.14$ & $101.41 \pm 1.77$ \\
\hline Triple & 401 & $2.26 \pm 0.06^{\mathrm{b}}$ & 279 & $5.44 \pm 0.11^{c}$ & $107.88 \pm 5.21^{b}$ & 21 & $8.40 \pm 0.40$ & $96.92 \pm 6.40$ \\
\hline Age of dam & & $* * *$ & & $* * *$ & $* * *$ & & $* * *$ & $* * *$ \\
\hline 1 year & 1332 & $2.24 \pm 0.06^{c}$ & 908 & $5.37 \pm 0.10^{c}$ & $105.92 \pm 4.85^{c}$ & 108 & $7.80 \pm 0.24 b$ & $90.86 \pm 3.63^{c}$ \\
\hline 2 year & 1837 & $2.30 \pm 0.06^{b}$ & 1333 & $5.69 \pm 0.09^{b}$ & $114.57 \pm 4.78^{b}$ & 148 & $8.51 \pm 0.22 a$ & $101.26 \pm 3.23^{b c}$ \\
\hline 3 year & 1546 & $2.32 \pm 0.06^{\mathrm{ab}}$ & 1174 & $5.79 \pm 0.09^{\mathrm{ab}}$ & $117.82 \pm 4.79^{\mathrm{ab}}$ & 125 & $8.54 \pm 0.22 a$ & $103.38 \pm 3.34^{\mathrm{ab}}$ \\
\hline 4 year & 1269 & $2.33 \pm 0.06^{\mathrm{ab}}$ & 928 & $5.82 \pm 0.10^{\mathrm{ab}}$ & $117.97 \pm 4.81^{\mathrm{ab}}$ & 92 & $8.47 \pm 0.24 a b$ & $101.88 \pm 3.61^{a b c}$ \\
\hline$\geq 5$ year & 2946 & $2.34 \pm 0.06^{\mathrm{a}}$ & 2152 & $5.86 \pm 0.09^{a}$ & $119.12 \pm 4.71^{a}$ & 219 & $8.98 \pm 0.20 a$ & $110.78 \pm 2.96^{a}$ \\
\hline Birth season & & $* * *$ & & $* * *$ & $* * *$ & & $* * *$ & $* * *$ \\
\hline Spring & 402 & $2.32 \pm 0.06^{\mathrm{b}}$ & 221 & $5.83 \pm 0.12^{\mathrm{a}}$ & $120.72 \pm 5.38^{a}$ & 42 & $9.78 \pm 0.32 a$ & $125.12 \pm 4.89^{\mathrm{a}}$ \\
\hline Summer & 2747 & $2.23 \pm 0.06^{c}$ & 2280 & $5.69 \pm 0.09^{a}$ & $116.22 \pm 4.68^{a}$ & 170 & $7.34 \pm 0.20 c$ & $83.02 \pm 2.98^{c}$ \\
\hline Autumn & 3475 & $2.38 \pm 0.06^{\mathrm{a}}$ & 2439 & $5.74 \pm 0.09^{a}$ & $112.84 \pm 4,66^{\mathrm{b}}$ & 308 & $7.83 \pm 0.18 c$ & $89.23 \pm 2.56^{c}$ \\
\hline Winter & 2306 & $2.29 \pm 0.06^{\mathrm{b}}$ & 1555 & $5.55 \pm 0.09^{b}$ & $110.54 \pm 4.71^{b}$ & 172 & $8.88 \pm 0.21 b$ & $109.16 \pm 2.99^{b}$ \\
\hline
\end{tabular}

BW: birth weight, W30: adjusted live weight at 30 days of age, ADG30: average daily gain from birth until 30 days, WW: adjusted weaning weight at 60 days of age, ADG60: average daily gain from birth until 60 days. NS: $P>0.05$. a, b, c: means within a column and class not followed by the same letter differ $(P<0.05)$.

${ }^{* * *} P<0.001$.

increased with the increasing age of the dam. Although the differences in mature size several authors referred that the weights at birth and weaning of offspring of young goat was lower than those born from older goats (Sánchez et al., 1994; Alexandre et al., 1999; Mourad and Anous, 1998; Portolano et al., 2002; Liu et al., 2005).

As it can be seen in Table 1, kids born from 1 year old goats had lower ADG30 and ADG60 than those which were born from 2, 3, 4 and $\geq 5$ year old does. Liu et al. (2005) reported that $A D G$ from birth to weaning of kids from first kidding was lower than those from older does, indicating that the poor condition of dams was responsible for reduced ADG from birth to weaning.

\subsection{Effect of birth season}

Kids born in autumn were heavier than animals born in the other three seasons. The lowest BW was found in those born in summer. The W30 of kids born at winter was the smallest. The WW was higher in spring than in winter, autumn and summer. The effect of season of birth can be explained by the changes in the climatic conditions from one season to another (Al-Shorepy et al., 2002 and Liu et al., 2005). As well as in Mediterranean there is a great influence of climate in the production and distribution of the biomass, with consequences in the palatability and the nutritive value of the grass and/or forage, affecting the nutrition conditions of females. Winter and summer are the worst conditions for goat production. In other studies, like the one of Al-Shorepy et al. (2002) in Arab United Emirates it is indicated that the season of birth had an influence on the W30, so the kids born in winter were significantly heavier than the ones born in summer.
As it can be seen from Table 1, ADG30 in kids born in spring and summer were higher than for those born in autumn and winter, whilst for the ADG60, kids which were born in spring had higher daily gain than the ones born in summer, autumn and winter. Kids born in summer and autumn had lower daily gain that those born in winter and spring.

\section{Conclusion}

This study showed the importance of certain environmental factors on growth traits. The BW, W30 and WW, as well as ADG30 and ADG60 were influenced by sex, type of birth, age of dam and birth season.

Even though birth weight is easy to measure, under extensive pasture conditions it is difficult to record it. The results of this study allow to estimate these traits in Serrana breed, and to predict the time when kids reach the adequate slaughter weight.

\section{Acknowledgement}

This work was a part of AGRO (INIA) project 246 "Caracterization of products with protected origin designation: Cabrito Transmontano and Borrego Terrincho".

\section{References}

Alexandre, G., Aumont, G., Mainaud, J.C., Fleury, J., Naves, M., 1999. Productive performances of Guadeloupean Creole goats during the suckling period. Small Rumin. Res. 34, 155-160.

Al-Shorepy, S.A., Alhadrami, G.A., Abdulwahab, K., 2002. Genetic and phenotypic parameters for early growth in Emirati goat. Small Rumin. Res. 45, 217-223.

Amoah, E.A., Gelaye, S., Guthrie, P., Rexroad Jr., C.E., 1996. Breeding season and aspects of reproduction of female goats. J. Anim. Sci. 74, 723-728. 
ANCRAS, 2009. Associação Nacional de Caprinicultores da Raça Serrana. http://www.ancras.pt/. Accessed in 25th May, 2009.

Browning Jr., R., Kebe, S.H., Byars, M., 2004. Preliminary assessment of Boer and Kiko does as maternal lines for kid performance under humid, subtropical conditions. S. Afr. J. Anim. Sci. 34 (Suppl. 1), http://www.sasas.co.za/sajas.html.

Das, S.M., Sendalo, D.S., 1992. Comparative performance of improved meat goats in Malya, Tanzania. Small Rumin. Res. Dev. Afr. http://www.fao.org/wairdocs/ilri/x5520b/x5520b19.htm.

Dhanda, J.S., Taylor, D.G., Murray, P.J., 2003. Part 1. Growth, carcass and meat quality parameters of male goats: effects of genotype and live weight at slaughter. Small Rumin. Res. 50, 57-66.

FAO, 2006. http://faostat.fao.org/faostat/. Last accessed February 2006.

Husain, S.S., Horst, P., Islam, A.B.M.M., 1996. Study on the growth performance of Black Bengal goats in different periods. Small Rumin. Res. 21 165-171.

IDRHa, 2005. Productos tradicionais com nomes protegidos. Apuramentos 2003. Instituto de Desenvolvimento Rural e Hidráulica. Direcção de Serviços de Planeamento, Divisão de Estudos Planeamentos e Prospectiva, Portugal, 53 pp.

Kadim, I.T., Mahgoub, O., Al-Ajmi, D.S., Al-Maqbaly, R.S., Al-Saqri, N.M., Ritchie, A., 2003. An evaluation of the growth, carcass and meat quality characteristics of Omani goat breeds. Meat Sci. 66, 203-210.

Liu, W., Zhang, Y., Zhou, Z., 2005. Adjustment for non-genetic effects on body weight and size in Angora goats. Small Rumin. Res. 59, 25-31.

Mahgoub, O., Lodge, G.A., 1996. Growth and body composition in meat production of Omani Batina goats. Small Rumin. Res. 19, 233-246.
Mahgoub, O., Lu, C.D., 1998. Growth, body composition and carcass tissue distribution in goats of large and small sizes. Small Rumin. Res. 27, 267-278.

Mourad, M., Anous, M.R., 1998. Estimates of genetic and phenotypic parameters of some growth traits in Common African and Alpine crossbred goats. Small Rumin. Res. 27, 197-202.

Portolano, B., Todaro, M., Finocchiaro, R., van Kaam, J.H.B.C.M., 2002. Estimation of the genetic and phenotypic variance of several growth traits of the sicilian girgentana goat. Small Rumin. Res. 45, 247-253.

Sánchez, G.F.F., Montaldo, V.H., Juárez, L.A., 1994. Enviromental and genetic effects on birth weight in graded-up goat kids. Can. J. Anim. Sci. 74, 397-400.

SAS, 2003. SAS/SAT User's Guide, release 9.1. SAS Institute Inc., Cary, NC USA (Licensed to Inst. Politécnico de Bragança).

Teixeira, A., Delfa, R., 1993. Trends in consumer preferences and market requirements for sheep and goat meat. In: Mette Roneklint, Sorensen (Ed.), Proceedinga of 44th Annual Meeting of the European Association for Animal Production, vol. II. Aarhus, Denmark, 134 pp.

Teixeira, A., 2003. Goat Sector in Portugal. International Goat Association Newsletter, February 2003, pp. 15-17.

Teixeira, A., Delfa, R., Albertí, P., 1998. Influence of production factors in the characteristics of meat from ruminants in Mediterranean areas. Proceedings of the International Symposium on the Basis of the Quality of Typical Mediterranean Animal Products. Badajoz and Zafra, Spain, 29 September-2 October 1996. EAAP Publication No. 90. The Netherlands: Wageningen Pers. 315-319.

Ugur, F., Savas, T., Dosay, M., Karabayir, A., Atasoglu, C., 2004. Technical note growth and behavioral traits of Turkish Saanen kids weaned at 45 and 60 days. Small Rumin. Res. 52, 179-184. 